\title{
Learning for life, for work, and for its own sake: the value (and values) of lifelong learning
}

\author{
Stephen Roche ${ }^{1}$
}

Published online: 14 September 2017

(C) Springer Science+Business Media B.V. and UNESCO Institute for Lifelong Learning 2017

Ninety percent of the world's children now complete primary schooling, 35 per cent of its youth go on to higher education, and roughly 85 per cent of adults are able to read and write, at least to a basic level (UIS 2016; World Bank 2017). Such figures would appear to fulfill the deepest desires of the political and social reformers of the nineteenth century, for whom education was a panacea for most of the ills of human societies, especially poverty, inequality and exploitation. While we have moved astonishingly close to realising the goal of universal access to education, we are achingly far from enjoying truly egalitarian societies. On the contrary, the last quarter-century has seen the gap between rich and poor widen in many parts of the world (though today's more unequally divided pie is larger than yesterday's, so even a smaller share may mean a bigger piece).

One of the risks in expecting so much of education is that we lose sight of its agents. Education, like any project, is constrained by the aims of its designers. Moreover, educators (in the broadest sense including not only teachers but also education theorists and policymakers) have always served a particular purpose or ideology. In the nineteenth century, public education largely prepared people to fit a certain station in life; to become the owners, managers, clerks and workers who together formed the "workforce" of capitalism and imperialism (indeed, many education systems are still yoked to such a caste mentality). More recently, education has often been conceived in economic terms as a commodity whose exchange permits entry into a putatively meritocratic "labour market". Is it any wonder that education systems have not delivered social equality if this was never their aim?

Stephen Roche

s.roche@unesco.org

1 UNESCO Institute for Lifelong Learning, Hamburg, Germany 
Yet alongside the various uses of education there has also existed the ideal. Establishment intellectuals like Cardinal Newman ${ }^{1}$ attempted to apply the values of the Hellenic schools to the age of industry, defining the university as a place to "educate the intellect to reason well in all matters, to reach out towards truth, and to grasp it" (Newman 1852, p. 126). Yet this vision of intellectual cultivation, however sincere, was also imbued with imperialist values, wedded to a hierarchical view of society, and necessarily reserved for a privileged elite. Others pursued a more democratic ideal. The folk high schools pioneered in Denmark by N.F.S. Grundtvig ${ }^{2}$ and the various forms of popular education that sprang from the socialist movements in Europe laid the ground for both the massification of public education in the 20th century, and the emergence of the concept of lifelong learning.

UNESCO initially played a key role in promoting lifelong learning. Through the Faure and Delors reports, published respectively in 1972 and 1996, it posited that "lifelong education" (Faure et al. 1972) and "learning throughout life" (Delors et al. 1996) are

meant to be more than organising principles of education - rather, they depict a worldview of a democratic society in which all citizens have equal learning opportunities which enable them to unleash their full potential and participate in building the societies in which they live (Elfert 2015, pp. 92-93).

Thus, the value of lifelong learning is inseparable from its values. It is about more than diversifying the loci and modi of learning, more than expanding access and opportunity, more indeed than transferring primary agency from the educator to the learner. Its value is nothing less than the inspiration for a new idea of human society.

In the last two decades, something remarkable has occurred in relation to lifelong learning; as a concept, it has been almost universally embraced. When the Organisation for Economic Co-operation and Development (OECD), World Bank and European Union all vigorously endorse lifelong learning, its long-standing champions are apt to feel both satisfaction and disquiet. The recent ascendance of lifelong learning is reminiscent of the way in which another concept - sustainable development - which similarly began as a radical proposal, has been adopted, co-opted and diluted of meaning. But every new movement begins with an idea. Lifelong learning, like sustainable development, is a notional germ from which a different kind of society may sprout; one that values learning both for its uses and its own sake and that likewise values people both for what they do and who they are. Such a "learning society" is not as distant or utopian a vision as it might at first seem. Its inception requires that we re-examine how and why we learn, and then harness our creativity to design systems of learning that enrich all aspects of our lives.

\footnotetext{
1 John Henry Newman (1801-1890) was a prominent English theologian, writer and educational reformer. He published a volume of lectures entitled The idea of a university (Newman 1852) before becoming the first rector of the newly established Catholic University of Ireland (now called University College Dublin) in 1854.

2 Danish theologian, philosopher and educationist Nikolaj Frederik Severin Grundtvig (1783-1872) is often referred to as the "father" of Scandinavian folk high schools, whose aim was to give workers and peasants an opportunity to broaden their minds and become more active members of society.
} 
When we consider that most of the world's education systems are built on nineteenth-century foundations, it should hardly surprise us that most of them are struggling to equip people with the skills needed to thrive in twenty-first-century employment. This crisis is particularly acute in technical and vocational education. In his article entitled "La prise en compte de la relation entre formation et emploi dans la réforme de l'éducation au Bénin : contribution à l'élaboration d'un nouveau modèle éducatif" ["Matching training to employment in educational reform in Benin: contribution to the development of a new educational model"], Abdel Rahamane Baba-Moussa looks at the challenges faced by a small developing country in tailoring its education system to the reality of the employment landscape. After independence, Benin, like many African countries, adopted a socialist economic model in which the state guaranteed employment to graduates of upper secondary and tertiary education. The collapse of the international socialist order post-1990 left Benin with an education and training system ill-equipped to deal with greater numbers of students and an economy no longer dominated by the state sector. The author describes a clear imbalance of supply and demand in higher education; for example, agricultural science and economics account for fewer than two per cent of tertiary-level students despite agriculture being the largest economic sector in terms of both output and employment. By stark contrast, the humanities and social sciences account for 52 per cent of third-level students. This he attributes not only to the former role of the state in absorbing graduates, but also to a "social devaluation of manual work in favour of intellectual work" ["dévalorisation sociale du travail manuel au profit du travail intellectuel"], a stubbornly enduring legacy of a colonial regime that represented civil service "white-collar" work as "more highly evolved" than manual, artisanal or self-employment.

Baba-Moussa proposes a more "holistic architecture" for the education and training system, one that integrates formal, non-formal and alternative structures to provide a ten-year basic education, to which professional and vocational training, geared to the demands of the labour market, may be added. He considers a more appropriate role for the state as mediator, helping people "read" or interpret the labour market and ensuring that they gain access to the necessary training to enter their chosen field of work. He also calls for new levels of cooperation within and between government agencies and ministries. It is in this new approach that he sees the best chance for a country like Benin to reach the targets set for itself in documents such as the Education Sector Plan - (Plan sectoriel de l'éducation; PSE) and internationally agreed goals such as Sustainable Development Goal 4. He concludes with the aspiration that this case study from Benin may provide impetus for research from other countries in the region.

One such country, comparable in terms of size and history, is Benin's nearneighbour, Ghana. Like Benin, Ghana underwent fundamental changes in the 1990s, with corresponding implications for the education system. Recognising that the state was not in a position to promise full employment, Ghana has switched to an emphasis on the development of "human capital" based on lifelong learning. An important tool for the development of a learning society capable of maximising human capital and responding organically to changes in the globalised labour market is a national qualifications framework (NQF) and a system to recognise 
knowledge and skills acquired in informal and non-formal contexts (e.g, in the workplace, home life, etc.). Ghana has taken the first step in this direction by launching a sub-framework focusing on technical and vocational education and training (TVET) in 2012.

In his article entitled "Expanding the frontiers of national qualifications frameworks through lifelong learning", Yaw Owusu-Agyeman argues that Ghana's National TVET Qualifications Framework (NTVETQF) represents the first step in developing a more comprehensive lifelong learning approach. Comparing national and international policies, he argues that the NTVETQF should address the issues of progression from informal and non-formal to formal modes of lifelong learning. He conceptualises the integration of lifelong learning within a broader NQF in four key domains - individual, institutional, industry, and state - and concludes that, for the NTVETQF to achieve its goal of facilitating access to further education and training while also promoting lifelong learning for all (including workers in the informal economy), effective integration of all modes of lifelong learning is required. Although this entails some challenges, such as recognition of prior learning and validation of all modes of learning, it will help to widen access to education and provide alternative pathways to achieve educational aspirations.

Staying with the subject of TVET, our next article focuses on teaching quality at a training academy in the Kurdistan region of Northern Iraq. The Kurdistan Regional Government (KRG) faces a dual challenge: rebuilding social and political institutions following the de-facto civil war that followed the 2003 US-led invasion of Iraq; and absorbing over a million refugees fleeing the Syrian civil war post-2012 and ISIS post-2014. The upheavals of the past three decades have taken an enormous toll on Iraq's education system, with particularly grave impact on teacher training and teaching quality, as Iraqi academics and scientists fled the country, leaving a chronic shortage of teachers and of teacher trainers. Years of resource starvation and overt politicisation of education left a legacy of untrained teachers and outdated methodologies and curricula. A large-scale needs analysis conducted by the United Nations and the World Bank in 2003 found that there was an urgent need to concentrate on "improving quality and modernizing the [educational] system in terms of teacher upgrading, and updating the curriculum and instruction methods" (UN and World Bank 2003, p. 14).

In their article entitled "Introducing active learning pedagogy into a technical and vocational education and training academy in Kurdistan, Iraq", Martina Dickson and Svend Erik Ladefoged study a TVET academy established in 2012 to provide unemployed youth with workplace-relevant training. A needs analysis showed that the academy's teachers were more skilled in technical content areas than in pedagogy. Perhaps as a result, predominantly teacher-centred approaches to teaching were observed. However, teaching and learning in TVET must consider active learning and practical training as core to its vocational purpose; technical and pedagogical skills are intrinsically linked, since a teacher cannot effectively pass on technical skills without the necessary pedagogical skills. It is on this premise that the authors based their project, which was designed to help teachers incorporate more active learning strategies. The authors' findings show that while some of the teachers had shifted towards using more dynamic teaching strategies, there was also 
reluctance to incorporate active learning. In their conclusion, the authors suggest that the insights gained from this project could be further empirically examined in a larger, multi-institutional study.

One of the difficulties of preparing young people for employment is that the demands of the labour market change very quickly, making it difficult for teachers, institutions and policymakers to stay "ahead of the curve". It is hardly a coincidence that many of the best known technological innovators of our age dropped out of university to start their own business. They saw a degree as a poor investment of their time. Luckily, many universities have embraced the idea of student entrepreneurship, releasing students from the need to choose between a degree and a business idea. Youth entrepreneurship has gained prominence in recent years, helping universities both to combat the "ivory tower" aspersion and to more actively contribute to their localities. However, few studies have investigated the characteristics of companies created by students in the university environment (known as "student spin-offs"). Most of the research on university-incubated entrepreneurship has focused on academic spin-off companies, enterprises created by teachers and researchers. In parallel, more research is needed into the role of universities in developing a local entrepreneurial ecosystem, as most of the literature on student entrepreneurship - especially focusing on entrepreneurial education - has ignored the contextual influences on how students create new businesses.

In their article entitled "Universities, local partnerships and the promotion of youth entrepreneurship", Éder D. Bezerra, Cândido Borges and Tales Andreassi set out to understand how universities bring together local partners in support of young entrepreneurs. The authors followed a multiple case study approach, analysing the business creation process and trajectory of six student spin-off companies incubated at two universities in north-eastern Brazil. They identified the processes, characteristics and actors involved in the formation of local networks that helped to develop business learning and knowledge creation. The narrative accounts of the respondents formed the basis for understanding the history of the companies studied, and fed into a discussion of the theoretical and practical aspects of the relationships between these companies and the universities involved as well as their local partners. As a theoretical contribution, this article analyses a type of business as well as a context that is still little explored in the literature; as a practical contribution, it offers insights into how to improve policies that support youth and student entrepreneurship.

A European Union (EU) policy paper developed in 2001 and entitled "Making a European area of lifelong learning a reality" (EC 2001) is frequently cited as marking the moment when lifelong learning became a central education and training strategy in the EU. Following the economic crisis of 2008, EU leaders came to the conclusion that lifelong learning and skills development represented the best response to the economic and demographic challenges facing the Union. While the adoption of lifelong learning as a policy priority at intergovernmental level marked a new departure, lifelong learning, in theory and practice, has a considerable pedigree in Europe, though these antecedents have generally been concerned more with social and democratic reform than with economic development. The popular 
universities (PUs) of France and Spain in the late nineteenth century were a particularly important manifestation of this movement. These institutions, which have survived to this day, are the subject of the next article in this issue, entitled "Popular universities: An alternative vision for lifelong learning in Europe".

The authors, Nelly P. Stromquist and Romina B. da Costa, carried out a qualitative survey in 23 Spanish and 21 French popular universities to examine whether their offerings meet community needs, to what extent they address emerging issues such as immigration, the refugee crisis, an aging population and youth unemployment, and whether they remain aligned with the original aims of PUs; fostering critical reflection on the social and economic environment with the overall purpose of improving society. In their evaluation, the authors link the grassroots approaches of PUs in Spain and France to the broader EU discourse on lifelong learning. Finally, they examine the ways in which PUs' approach contests the dominant consensus on the meaning and scope of lifelong learning, constituting a vision and reality of lifelong learning which is more expansive, inclusive and accessible than that proposed by the EU. Whereas recent EU policies place the building of marketable skills, vocational training and job preparation for a competitive workplace at the centre of their lifelong learning objectives, PUs foster a love of learning for sheer enjoyment, socialisation and self-improvement.

The final article of this issue, entitled "'We also wanted to learn': Narratives of change from adults literate in African languages" looks at the value of literacy as expressed by adults who learned to read and write in their native languages. The authors, Joel Trudell and Ian Cheffy, draw on adult learners' reflections on the significance of literacy and numeracy in their everyday lives as evidenced in interviews conducted in 2014 and 2015 in rural sites in five African countries: Ethiopia, Kenya, Cameroon, Burkina Faso and Ghana. The research approach was influenced by the Most Significant Change (MSC) method of monitoring and evaluation, which collects and examines narratives that reveal beneficiaries' perceptions of change related to a given programme, without imposing preestablished indicators. In the rural adult learners' view, literacy enabled lifelong learning outcomes that rivalled the results of primary schooling. Literacy programme graduates demonstrated extensive ongoing learning after they first learned to read, write and calculate, consequently acquiring new literacy practices and new understandings of themselves.

This study demonstrates the value of appreciating the demand side of educational access, of understanding and catering to the motivations of learners. It also emphasises that at least as much or even more learning takes place in the application of literacy skills to daily life as in learning the skills themselves. Finally, it provides an all-too-rare opportunity to understand the "insider perspective" on learning outcomes. Programme providers need to pay more attention to the voices of the learners when they describe the opportunities for positive change and personal development that literacy provides. From the beneficiaries' point of view, literacy instruction was an entrée to learning; it represented the opportunity to learn in the language and the circumstances that were most relevant to their contexts. 


\section{References}

EC (European Commission). (2001). Making a European area of lifelong learning a reality. Brussels: European Commission. Retrieved 29 August 2017 from http://eur-lex.europa.eu/LexUriServ/ LexUriServ.do?uri=COM:2001:0678:FIN:EN:PDF.

Delors, J., et al. (1996). Learning: The treasure within. Report to UNESCO of the International Commission on Education for the twenty-first century. Paris: UNESCO.

Elfert, M. (2015). UNESCO, the faure report, the delors report, and the political utopia of lifelong learning. European Journal of Education, 50(1), 88-100.

Faure, E., Herrera, F., Kaddoura, A., Lopes, H., Petrovsky, A. V., Rahnema, M., et al. (1972). Learning to be: The world of education today and tomorrow. Paris: UNESCO.

Newman, J. H. (1852). The idea of a university. London: Longmans, Green, and Co. Retrieved 27 August 2017 from http://www.newmanreader.org/works/idea/.

UIS (UNESCO Institute for Statistics). (2016). UIS Fact Sheet September 2016, No. 38. Montreal: UNESCO Institute for Statistics. Retrieved 26 August 2017 from http://uis.unesco.org/en/news/ international-literacy-day-2016.

UN (United Nations) \& World Bank. (2003). Joint Iraq needs assessment report. New York/Washington, DC: United Nations and World Bank. Retrieved 28 August 2017 from http://siteresources. worldbank.org/IRFFI/Resources/Joint+Needs+Assessment.pdf.

World Bank. (2017). Online databank. Retrieved 28 August 2017 from https://data.worldbank.org/ indicator/SE.TER.ENRR?year_high_desc=true. 